\title{
Comparative characterization of surface sludge deposits from fourteen French vertical flow constructed wetlands sewage treatment plants using biological, chemical and thermal indices
}

Manon KANIA, Mathieu GAUTIER, Anne IMIG, Philippe MICHEL, Rémy GOURDON

\section{$\rightarrow$ To cite this version:}

Manon Kania, Mathieu Gautier, Anne Imig, Philippe Michel, Rémy Gourdon (2019). Comparative characterization of surface sludge deposits from fourteen French vertical flow constructed wetlands sewage treatment plants using biological, chemical and thermal indices. Science of The Total Environment, 647, 464-473.

https://doi:10.1016/j.scitotenv.2018.07.440

Please contact the corresponding author (mathieu.gautier@insa-lyon.fr ) if you are interested by a copy of the article published in the journal. 
Comparative characterization of surface sludge deposits from fourteen French vertical

\section{flow constructed wetlands sewage treatment plants using biological, chemical and}

\section{thermal indices}

M. Kania ${ }^{a, b}$, M. Gautier a, ${ }^{a}$, A. Imig a, P. Michel ${ }^{b}$ and R. Gourdon ${ }^{a}$

${ }^{a}$ Univ Lyon, INSA Lyon, DEEP (Déchets Eaux Environnement Pollutions), EA 7429, 69621 Villeurbanne Cedex, France

${ }^{\mathrm{b}}$ SCIRPE, 5 Allée Alban Vistel, 69110 Sainte-Foy-Lès-Lyon, France

\section{Graphical abstract}

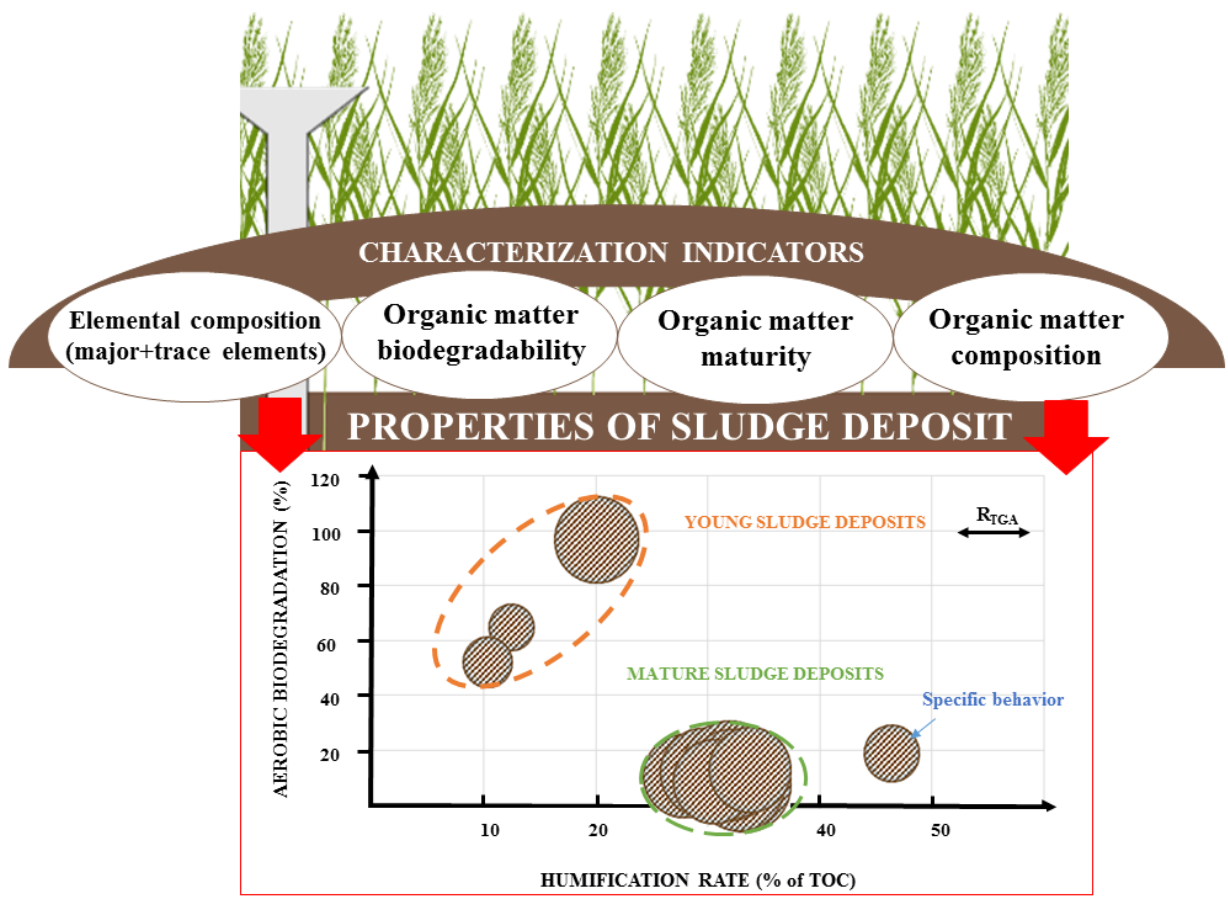

\section{Highlights}

- Particulate organic matter (POM) in sludge deposits (SD) exhibits specific properties.

- Young deposits ( $\leqslant 1 \mathrm{y})$ and mature de-posits $(>3 \mathrm{y})$ identified as 2 distinct groups.

- Additional pretreatments affected young-age sludge deposits characteristics.

- State of maturation of POM in SD inter-mediate between peat and wet meadows 


\section{Abstract}

Due to their design and mode of operation, French Vertical Flow Constructed Wetlands (VFCWs) accumulate suspended solids from the inflow wastewater in the form of a sludge layer at the surface of the first filter. In order to maintain the treatment performance over the long term, the characteristics of the sludge deposits and their evolution have to be well described. In this objective, a panel of sludge deposit samples taken from 14 French VFCW sewage treatment plants was investigated. Elemental composition and organic matter content, nature and reactivity were analyzed. Results clearly revealed two categories of sludge deposits, namely the "young-age plants" type (1 year of operation and less) and the "mature plants" type (3 years of operation and more). Sludge deposits from the "mature plants" exhibited same biological, physical and chemical properties. Their organic matter was globally less abundant, more humified and less biodegradable than in the young-age plants type. Their overall contents in trace metals were also higher, although in a limited manner. The effect of additional treatments, particularly $\mathrm{FeCl}_{3}$ injection for phosphorus precipitation, was observable in the "young-age plants" group. Finally, the sludge deposits sampled from one particular plant with specific operating conditions were found to exhibit very different characteristics from those of either groups identified. This observation underlined the influence of local conditions on the typology of the sludge deposits.

\section{Keywords}

Sludge deposits; Constructed wetland; indices; Characterization; Organic matter; Ageing *Corresponding author.

E-mail addresses: manon.kania@insa-lyon.fr (M. Kania), mathieu.gautier@insa-lyon.fr (M. Gautier), pmi@scirpe.fr (P. Michel), remy.gourdon@insa-lyon.fr (R. Gourdon). 


\section{Introduction}

French Vertical Flow Constructed Wetlands (VFCWs) have become in the recent years in France the sewage treatment system most widely used in rural communities of $\leq 2000$ Population Equivalent (Bellin, 2016). This rapid development may be explained by the high level of performance of these systems, their good social acceptability and landscape integration, their low energy requirements, easy operation, and low maintenance (Liu et al., 2015a; Semeraro et al., 2015; Wu et al., 2014).

The so-called "French VFCW system" comprises two stages of filters where the first stage is fed with unsettled raw wastewater. This design results in the formation of a sludge layer at the surface of the first filter which has mainly been considered until recently through its hydraulic aspects and its negative consequences with regards to the potential risk of clogging (Hua et al., 2018; Knowles et al., 2011; Nivala et al., 2012; Yang et al., 2018). Yet, the sludge layer may contribute positively to the treatment efficiency. For example, suspended solids removal, water retention and the biodegradation or retention of pollutants may be improved (Chazarenc \& Merlin, 2005; Kim et al., 2013; Molle, 2014). On the other hand; the retention of most of feed organic matter within the sludge layer may limit the efficiency of subsequent denitrification (Lee et al., 2009; Van Oostrom \& Russell, 1994). The effective roles of the sludge layer in the system may depend on its structural, compositional and reactional properties which are controlled by numerous factors, such as the composition of the influent wastewater, the operating conditions of the plant, or other local environmental factors (Fu et al., 2015). Although extensive work has already been published on similar issues in the fields of natural wetlands (Grasset et al., 2017; Rouwane et al., 2017), anthropic sediment (Badin, 2009; Huot, 2013), activated sludge (Alvarenga et al., 2015; Lachassagne, 2015), or sludge drying reed beds (SDRB) (Collard et al., 2017; Nielsen, 2011; Nielsen \& Bruun, 2015; Nielsen \& Larsen, 2016; Nielsen \& Willoughby, 2005; Vincent et al., 2012), very few studies have focused on VFCWs' 
surface sludge deposits (Bois et al., 2015; Chazarenc \& Merlin, 2005; Kim et al., 2013; Kim et al., 2015). Molle (2014) and Perron et al. (2007) reported the influence of the VFCW plant design and operating conditions, such as organic and hydraulic loads or feed and rest periodicity. Kim et al. (2013), reported that although mainly organic, sludge deposits contained significant amounts of inorganic constituents originating from the local geological background or generated by possible operations of pretreatment of the influent such as phosphate precipitation by $\mathrm{FeCl}_{3}$ addition. Kim et al. (2013) and Kania et al. (2018, 2018a) investigated the extent of organic matter evolution within the sludge deposits, such as mineralization. Finally, the authors of this study reported structural properties data of surface sludge deposits in a recent article (Kania et al., 2018b). In the specific context of sludge drying reed bed systems, few studies investigated the mineralization of the sludge and the organic matter stabilization (Masciandaro et al., 2017; Nielsen, 2005; Nielsen et al., 2014; Peruzzi et al., 2017; Peruzzi et al., 2013).

The objective of the present study was to contribute to a better description of the properties of sludge deposits using chemical, biological and thermochemical methods. Samples from fourteen VFCW sewage treatment plants in operation in France were analyzed to assess whether specific typologies would be observed and, if so, identify the dominant factors of influence, especially with regards to the particulate organic matter (POM).

\section{Materials and methods}

\subsection{Sites of investigation}

Fourteen French VFCW sewage treatment plants located in the south-eastern part of France, were selected for the study. The treatment plants were all equipped with a preliminary gridding stage set between 3 and $30 \mathrm{~mm}$ to remove coarse solids and debris. Four of them were also equipped with a sand trap (Table 1). Three typical types of VFCW process designs were represented in the selected plants: 
- Process type I, usually referred to as the "classical French system", where gridded, unsettled raw wastewater was percolated through two successive stages of vertical flow filters.

- Process type II, where an additional stage of aerobic biological trickling filter was used to treat gridded wastewater prior to the two successive stages of vertical flow filters,

- Process type III, comprising the same operations as in type II plus the introduction of a $\mathrm{FeCl}_{3}$ solution into the outlet of the aerobic trickling filter in order to precipitate phosphorus prior to infiltration through the two successive stages of filters. 
Table 1 Characteristics of the 14 French VFCW sewage treatment plants selected for the study.

\begin{tabular}{|c|c|c|c|c|c|c|c|c|c|}
\hline \multirow{2}{*}{$\begin{array}{l}\text { VFCW } \\
\text { plants }\end{array}$} & \multirow{2}{*}{$\begin{array}{l}\text { Process } \\
\text { type }\end{array}$} & \multicolumn{5}{|c|}{ Process line stages } & \multirow{2}{*}{$\begin{array}{c}\text { Number of } \\
\text { years of } \\
\text { operation at } \\
\text { sampling date }\end{array}$} & \multirow{2}{*}{ 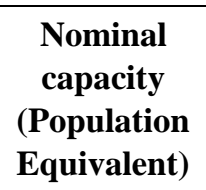 } & \multirow{2}{*}{$\begin{array}{c}\text { Average } \\
\text { hydraulic load } \\
\left(\mathbf{m}^{3} / \mathbf{y}\right)\end{array}$} \\
\hline & & $\begin{array}{c}\text { Gridding / } \\
\text { sieving }\end{array}$ & Sand trap & $\begin{array}{l}\text { Trickling } \\
\text { filter }\end{array}$ & $\underset{\text { injection }}{\mathrm{FeCl}_{3}}$ & $\begin{array}{l}\text { Saturation of } \\
1^{\text {st }} \text { stage filter }\end{array}$ & & & \\
\hline BAG1 & \multirow{7}{*}{$\begin{array}{l}\text { Classical } \\
\text { French } \\
\text { VFCW }\end{array}$} & \multirow{14}{*}{ Yes } & Yes & \multirow{7}{*}{ No } & \multirow{10}{*}{ No } & \multirow{9}{*}{ Unsaturated } & 11 & 1100 & 56940 \\
\hline BAG2 & & & No & & & & 8 & 500 & 23725 \\
\hline SABAG & & & No & & & & 7 & 800 & 81030 \\
\hline VIL & & & No & & & & 7 & 350 & 11315 \\
\hline BAG3 & & & No & & & & 4 & 290 & 6935 \\
\hline PRE & & & No & & & & 1 & 700 & 51830 \\
\hline RAM & & & No & & & & 0.5 & 350 & 13505 \\
\hline BAY & \multirow{2}{*}{$A Z O E^{\circledR}$} & & No & \multirow{7}{*}{ Yes } & & & 7 & 1200 & 32850 \\
\hline MIN & & & No & & & & 6 & 1000 & 25185 \\
\hline NEU & $A Z O E-N^{\circledR}$ & & Yes & & & \multirow{4}{*}{$\begin{array}{l}\text { Partially } \\
\text { saturated }\end{array}$} & 4 & 1600 & 75555 \\
\hline VER & \multirow{3}{*}{$A Z O E-N P^{\circledast}$} & & No & & \multirow{4}{*}{ Yes } & & 11 & 1100 & 44165 \\
\hline ORB & & & Yes & & & & 5 & 1500 & 126290 \\
\hline COR & & & No & & & & 0.5 & 1000 & 51830 \\
\hline MAT & $A Z O E-P^{\circledR}$ & & Yes & & & Unsaturated & 5 & 1600 & 68620 \\
\hline
\end{tabular}


These processes were further divided into two sub-categories according to the level of

4 saturation of the first-stage filter as shown in Table 1. Full drainage (unsaturated conditions) was implemented to ensure good aeration in all process type I plants (“classical French system”) and in some plants of process types II and III patented as $\mathrm{AZOE}^{\circledR}$ and $\mathrm{AZOE}-\mathrm{P}^{\circledR}$ respectively.

Partially saturated conditions were implemented in the other plants of types II and III (patented as $\mathrm{AZOE}-\mathrm{N}^{\circledR}$ and $\left.\mathrm{AZOE}-\mathrm{NP}^{\circledR}\right)$ in the objective to allow aeration of the upper unsaturated zone for nitrification, and anoxic conditions in the lower flooded zone for denitrification. More details were given in a previous article (Kania et al., 2018b; Kim et al., 2014).

\subsection{Sampling and preparation of the sludge deposits samples}

Sludge deposits were sampled in winter time between January and March 2015 from most wetlands, COR was sampled in November 2015 and RAM and PRE in February 2017 due

to their more recent dates of implementation of these wetlands. The annual load of dry solids

varied from one constructed wetland to another depending on its nominal design and its actual operating conditions. It was estimated between 20 and $35 \mathrm{~kg}$ of dry solids per year and $\mathrm{m}^{2}$ of first stage filter cells. At the time of the field sampling operations, the sludge layer had not yet been removed from any of the wetlands and it has not been removed since. The lower part of the layer therefore contained deposits from the very beginning of the plant operation, whereas the upper part contained fresh deposits. The entire depth of the sludge layer was sampled on each site in order to obtain average samples representative of the mean composition of the sludge deposits over the whole period of operation of the VFCW plants.

All samples were taken following the same protocol from the stage filters. A few kilograms of deposits were taken by shoveling the entire depth of the sludge layer from 5 to 10 spots (depending on the filter size) at the surface of the cell under resting period for 0-1 week. The sampling spots were randomly located at a distance of at least $5 \mathrm{~m}$ one from each other and at least $2 \mathrm{~m}$ from the feed pipes. The samples taken from each spot were treated on site to extract 
manually reeds rhizomes, and possible traces of gravels. They were then carefully homogenized by quarting and mixing together with shovels. The representative samples from each plant thereby constituted were then taken to the laboratory within a maximum of $4 \mathrm{~h}$. They were transported to the lab by car placed in a non-heated trunk at a maximal temperature of $10^{\circ} \mathrm{C}$ due to the winter season. There, an aliquot fraction of each sample was used to determine water content and the organic content of the dry solids. The rest was dried in thin layers at $35^{\circ} \mathrm{C}$ for one day, finely grinded and stored at $4^{\circ} \mathrm{C}$.

\subsection{Analytical methods}

\subsubsection{General analytical parameters}

Upon reception in the laboratory, a few grams of fresh samples from each plant were dried in triplicates in an oven at $105^{\circ} \mathrm{C}$ until they reached a constant mass in order to determine their humidity. Dry solids were then burnt in an oven at $550^{\circ} \mathrm{C}$ for four hours to determine their organic matter contents. The rest of each sample was spread in thin layers of $1-2 \mathrm{~cm}$ on a laboratory bench and air-dried for 1 day at $35^{\circ} \mathrm{C}$, then grinded down to less than $1 \mathrm{~mm}$ to obtain "dry powdered samples" which were stored at $4{ }^{\circ} \mathrm{C}$ and used for all the other analyses.

Elemental analyses were done by alkaline fusion $\left(\mathrm{LiBO}_{2}\right)$ followed by acid digestion $\left(\mathrm{HNO}_{3}\right)$ and subsequent analyses of the solutions by inductively coupled plasma atomic emission spectrometry (ICP-AES) (IRIS Advantage ERS, Thermo Scientific). The following elements were analyzed : silicon $(\mathrm{Si})$, aluminum $(\mathrm{Al})$, iron $(\mathrm{Fe})$, manganese $(\mathrm{Mn})$, magnesium $(\mathrm{Mg})$, calcium $(\mathrm{Ca})$, sodium $(\mathrm{Na})$, potassium $(\mathrm{K})$, titanium $(\mathrm{Ti})$ and phosphorus $(\mathrm{P})$. Trace metals chromium $(\mathrm{Cr})$, copper $(\mathrm{Cu})$, nickel $(\mathrm{Ni})$, zinc $(\mathrm{Zn})$, cadmium $(\mathrm{Cd})$ and lead $(\mathrm{Pb})$ were analyzed using a Sciex Perkin Elmer ELAN 5000a. ICP-mass spectrometer.

Organic carbon contents were determined by burning at $1400^{\circ} \mathrm{C} 1 \mathrm{~g}$ of dry powdered samples, previously de-carbonated with acid and under high temperature, and by infrared 
absorption with a Carbon - Sulfur EMIA 320V2 (HORIBA).Total nitrogen contents were measured by burning $1 \mathrm{~g}$ of powdered samples at $1050^{\circ} \mathrm{C}$ under a flow of helium and oxygen mixture in microanalyzer designed and developed at UMR 5280 Institute of Analytical Sciences which operates according to the Dumas method.

\subsubsection{Thermogravimetric and differential thermal analysis (TGA/DSC)}

Thermogravimetric analyses (TGA) were carried out using a METTLER TOLEDO TGA analyzer whose temperature precision was $\pm 0.5^{\circ} \mathrm{C}$ and microbalance sensitivity less than $\pm 0.1 \mathrm{mg}$. A dry mass of $\pm 20 \mathrm{mg}$ of each sample was heated from $35^{\circ} \mathrm{C}$ to $900^{\circ} \mathrm{C}$ at a rate of $10^{\circ} \mathrm{C} / \mathrm{min}$, under a flow of air of $50 \mathrm{~mL}$ per minute. The analyses were done in duplicates and blank experiments were carried under the same conditions as the assays but without any sample. The mass loss due to thermal degradation of the sample was recorded as a function of the temperature. Heat fluxes were also recorded during the process by differential scanning calorimetry (DSC).

$\mathrm{R}_{\mathrm{TGA}}$ index was calculated from experimental data as the ratio of the mass loss recorded between 200 and $400^{\circ} \mathrm{C}\left(\triangle \mathrm{m}_{1}\right)$ to that recorded between 400 and $600^{\circ} \mathrm{C}\left(\triangle \mathrm{m}_{2}\right)$, as proposed by several authors (Stevenson, 1982 ; Fernandez et al., 2012). In each given range of temperature, the unit mass heat release, also called "energy density" E (in J.mg ${ }^{-1}$ ), was also calculated from the ratio between the surface area of the corresponding peak in DSC profiles over the mass loss recorded in the same range of temperatures $\left(\mathrm{E}_{1}\right.$ and $\left.\mathrm{E}_{2}\right)$. The $\mathrm{R}_{\mathrm{DSC}}$ index was finally calculated as the ratio of $\mathrm{E}_{2} / \mathrm{E}_{1}$ (Achour, 2008).

\subsubsection{Determination of humification rate}

The contents in humic-like and fulvic-like substances (referred to as HULIS and FULIS, respectively) were analyzed to evaluate the humification degree of the organic matter in the sludge deposits (Albrecht, 2007). The protocol for the HULIS and FULIS extraction was 
adapted from Serra-Wittling et al. (1996). HULIS and FULIS were extracted by suspending for $2 \mathrm{~h}$ under constant agitation $1 \mathrm{~g}$ of powdered samples in $50 \mathrm{~mL}$ of a $0.1 \mathrm{M}$ sodium hydroxide aqueous solution. The suspensions were then centrifuged at $10000 \mathrm{~g}$ for $15 \mathrm{~min}$ and vacuum filtered at $0.45 \mu \mathrm{m}$ using Sartorius cellulose acetate filters. The solutions, containing HULIS and FULIS fractions were analyzed for total organic carbon (TOC) using a Shimadzu TOC-L analyzer, then acidified to $\mathrm{pH} 1.5$ with $1 \mathrm{M}$ sulfuric acid aqueous solution and left at rest overnight at $+4^{\circ} \mathrm{C}$ to allow precipitation of HULIS fraction. FULIS fraction was collected in solution by centrifugation at $6000 \mathrm{~g}$ for $15 \mathrm{~min}$ followed by filtration at $0.45 \mu \mathrm{m}$. The solution was analyzed for TOC using the same protocol as for the HULIS + FULIS extracts.

The proportion of HULIS + FULIS in the organic matter was taken as an indicator of the degree of humification of the sludge organic matter and calculated as follows:

Humification rate $=100 \times \frac{[\text { HULIS }]+[\text { FULIS }]}{\text { TOC }}$

\subsubsection{Biodegradation under aerobic conditions}

Respirometric assays were conducted to evaluate the biodegradability of the sludge deposits considered here as an indicator of stability of their organic matter. A given mass of each powdered sample, calculated to contain $75.5 \mathrm{mg}$ of organic matter, was introduced into $500 \mathrm{~mL}$ BOD flasks containing $10 \mathrm{~mL}$ of a mineral medium made of an aqueous solution of 28.25 g.L $\mathrm{L}^{-1} \mathrm{KH}_{2} \mathrm{PO}_{4} ; 146.08$ g.L. $\mathrm{K}_{2} \mathrm{HPO}_{4} ; ; 3.66$ g.L ${ }^{-1} \mathrm{CaCl}_{2} ; 28.64$ g.L $\mathrm{L}^{-1} \mathrm{NH} 4 \mathrm{Cl} ; 3.06$ g.L $\mathrm{L}^{-1}$ $\mathrm{MgSO}_{4}, 0.7$ g.L $\mathrm{L}^{-1} \mathrm{FeSO}_{4}$ and 0.4 g.L $\mathrm{L}^{-1} \mathrm{ZnSO}_{4}$ (Liu et al., 2015b). The flasks were then inoculated with $10 \mathrm{~mL}$ of a seed suspension prepared from biological sludge obtained from a municipal wastewater activated sludge treatment plant located in Villeurbanne (France) and cultivated in the laboratory prior to the beginning of the assays. They were finally spiked with ca. $0.2 \mathrm{~mL}$ of a 5 g.L $\mathrm{L}^{-1}$ allylthio-urea aqueous solution used as a nitrification inhibitor, hermetically closed by manometric caps to monitor pressure variations, and incubated at $30 \pm 1^{\circ} \mathrm{C}$ in the dark. Carbon 
100 dioxide formed from biodegradation was trapped by sodium hydroxide pellets placed in a 101 specific compartment in the headspace of the test flasks. The recorded pressure therefore 102 decreased proportionally to the oxygen consumed and was subsequently converted into BOD 103 values expressed in $\mathrm{mg} \mathrm{O}_{2}$ per $\mathrm{g}$ of sludge TOC.

Biodegradability was finally calculated according to eqn. (2) from the ratio between the 105 cumulated consumption of $\mathrm{O}_{2}(\mathrm{~g})$ over 14 days of incubation $\left(\mathrm{BOD}_{14}\right)$ and the theoretical oxygen demand (ThBOD) of $2667 \mathrm{mg} \mathrm{O}_{2}$ per $\mathrm{g}$ of TOC (corresponding to a consumption of 32

$107 \mathrm{~g} \mathrm{O}_{2}$ for a complete bio-oxidation of $12 \mathrm{~g} \mathrm{C}$ based on a stoichiometry of 1 mole of $\mathrm{O}_{2}$ for 1 mole 108 of $\mathrm{C}$ assuming that carbon in the sludge organic constituents was at an average degree of 109 oxidation of zero).

110 Biodegradability $(\%)=\frac{\mathrm{BOD}_{14}\left(\mathrm{gO}_{2} \text { per } \mathrm{g} \text { TOC }\right)}{2.667} \times 100$

\section{3 . Results and discussion}

\section{3.1. Organic content and elemental composition}

\subsubsection{Organic content}

Table 2 shows the average contents in organic matter and organic carbon analyzed in

115 the surface deposits samples. Organic matter (OM) contents ranged between 50.3 and $86.2 \%$ of 116 total dry weight $(\% \mathrm{w} / \mathrm{w})$. Regardless of their wetland of origin, the surface deposits were 117 therefore in all cases mostly organic material. 
Table 2 General composition of sludge deposits samples.

\begin{tabular}{|c|c|c|c|c|c|c|c|c|c|c|c|c|c|c|c|c|c|c|c|c|c|}
\hline \multirow{2}{*}{ VFCW labels ${ }^{\mathrm{a}}$} & $\mathrm{OM}^{\mathrm{b}}$ & $\mathrm{TOC}^{\mathrm{c}}$ & $\mathrm{Si}^{\mathrm{d}}$ & $\mathrm{Ca}^{\mathrm{d}}$ & $\mathrm{Al}^{\mathrm{e}}$ & $\mathrm{Fe}^{\mathrm{d}}$ & $\mathrm{Mg}^{\mathrm{e}}$ & $\mathrm{Na}^{\mathrm{f}}$ & $\mathrm{K}^{\mathrm{d}}$ & $\mathrm{Mn}^{\mathrm{e}}$ & $\mathrm{Ti}^{\mathrm{e}}$ & $\mathrm{P}^{\mathrm{d}}$ & $\mathrm{TN}^{\mathrm{g}}$ & TOC/TN & $\mathrm{Cr}^{\mathrm{e}}$ & $\mathrm{Cu}^{\mathrm{d}}$ & $\mathrm{Ni}^{\mathrm{d}}$ & $\mathrm{Zn}^{\mathrm{e}}$ & $\mathrm{Cd}^{\mathrm{f}}$ & $\mathrm{Pb}^{\mathrm{d}}$ & $\sum_{\mathrm{h}} \operatorname{metals}$ \\
\hline & \multicolumn{2}{|c|}{$\% \mathrm{w} / \mathrm{w}$ of DM } & \multicolumn{11}{|c|}{$\% \mathrm{w} / \mathrm{w}$ of DM } & & \multicolumn{7}{|c|}{$\mathrm{mg} \cdot \mathrm{kg} \mathrm{DM}^{-1}$} \\
\hline BAG1 & 59.0 & 24.7 & 7.7 & 2.6 & 2.1 & 1.0 & 0.3 & 0.2 & 0.5 & 0.02 & 0.2 & 1.2 & 4.0 & 6.2 & 49.8 & 338.0 & 23.2 & 615.6 & 1.0 & 43.7 & 1071 \\
\hline BAG2 & 57.4 & 24.2 & 13.3 & 2.9 & 2.0 & 0.9 & 0.3 & 0.2 & 0.7 & 0.01 & 0.2 & 0.8 & 3.3 & 7.2 & 41.4 & 363.8 & 21.7 & 810.2 & 1.2 & 37.2 & 1276 \\
\hline SABAG & 60.3 & 21.0 & 11.6 & 2.6 & 1.8 & 1.4 & 0.3 & 0.2 & 0.6 & 0.04 & 0.2 & 1.1 & 3.6 & 5.8 & 46.3 & 1162.0 & 23.1 & 557.4 & 1.0 & 33.4 & 1823 \\
\hline VIL & 60.9 & 22.7 & 10.5 & 2.4 & 2.4 & 1.2 & 0.3 & 0.1 & 0.5 & 0.01 & 0.3 & 1.2 & 3.4 & 6.7 & 46.5 & 425.2 & 18.0 & 430.0 & 0.6 & 31.9 & 952 \\
\hline BAG3 & 50.3 & 18.4 & 13.2 & 3.5 & 2.4 & 1.4 & 0.3 & 0.3 & 0.7 & 0.02 & 0.2 & 1.0 & 3.1 & 5.9 & 59.3 & 282.3 & 25.1 & 481.4 & 1.0 & 34.7 & 884 \\
\hline PRE & 86.2 & 36.4 & 2.1 & 2.5 & 0.4 & 0.2 & 0.1 & 0.1 & 0.2 & $<$ D.L. & 0.1 & 0.5 & 1.5 & 24.7 & 19.3 & 216.9 & 7.7 & 463.1 & 0.4 & 13.6 & 721 \\
\hline RAM & 84.3 & 32.3 & 3.4 & 3.2 & 0.6 & 0.3 & 0.2 & 0.1 & 0.2 & $<$ D.L. & 0.1 & 0.7 & 2.1 & 15.6 & 18.4 & 304.7 & 10.0 & 481.0 & 0.6 & 18.1 & 833 \\
\hline BAY & 70.5 & 28.5 & 3.3 & 4.7 & 1.5 & 0.5 & 0.3 & 0.1 & 0.3 & 0.01 & 0.2 & 1.9 & 4.5 & 6.4 & 34.5 & 232.9 & 20.3 & 968.9 & 1.5 & 121.5 & 1380 \\
\hline MIN & 73.5 & 28.2 & 5.0 & 3.5 & 1.3 & 0.6 & 0.4 & 0.2 & 0.4 & 0.02 & 0.3 & 1.4 & 4.8 & 5.9 & 51.9 & 195.9 & 30.3 & 731.6 & 0.9 & 32.2 & 1043 \\
\hline NEU & 58.6 & 21.7 & 9.6 & 3.7 & 2.3 & 1.2 & 0.4 & 0.3 & 0.7 & 0.04 & 0.2 & 1.1 & 3.6 & 6.0 & 51.8 & 223.9 & 26.9 & 573.9 & 1.2 & 45.4 & 923 \\
\hline VER & 62.0 & 23.0 & 5.7 & 3.8 & 2.1 & 3.5 & 0.3 & 0.1 & 0.4 & 0.02 & 0.2 & 2.0 & 3.8 & 6.1 & 57.4 & 622.5 & 30.5 & 1218.5 & 1.6 & 64.2 & 1995 \\
\hline ORB & 58.2 & 22.7 & 7.3 & 3.8 & 2.0 & 3.5 & 0.3 & 0.1 & 0.5 & 0.03 & 0.2 & 1.6 & 3.6 & 6.2 & 74.0 & 379.6 & 36.7 & 952.9 & 1.3 & 48.9 & 1493 \\
\hline $\mathrm{COR}$ & 72.0 & 24.7 & 2.8 & 4.6 & 0.8 & 5.2 & 0.3 & 0.2 & 0.5 & 0.02 & 0.2 & 2.5 & 4.1 & 5.9 & 51.4 & 691.4 & 21.0 & 908.8 & 1.0 & 37.2 & 1711 \\
\hline MAT & 50.6 & 14.0 & 11.2 & 1.6 & 3.2 & 5.9 & 0.4 & 0.4 & 1.2 & 0.5 & 0.3 & 2.0 & 2.5 & 5.5 & 57.6 & 201.7 & 23.4 & 744.7 & 1.1 & 68.7 & 1097 \\
\hline
\end{tabular}

121 b Analytical results from the replicates of each sample did not exceed $\pm 2.5 \%$

$122{ }^{\mathrm{C}}$ Relative uncertainty of $1-2 \%$

123 d Relative uncertainty of 5\% 
e Relative uncertainty of $10 \%$

${ }^{\mathrm{f}}$ Relative uncertainty of $15 \%$

${ }^{g}$ Relative uncertainty of $0.3 \%$

${ }^{\mathrm{h}} \sum$ metals $=[\mathrm{Cr}]+[\mathrm{Cu}]+[\mathrm{Ni}]+[\mathrm{Zn}]+[\mathrm{Cd}]+[\mathrm{Pb}]$. 
Fig. 1 illustrates the plot of organic matter contents of the surface deposits vs. the number of years of operation of the VFCW sewage treatment plants of origin. The graph showed that deposits from young systems with newly established thin sludge layers of about 1$3 \mathrm{~cm}$ contained larger concentrations of organic matter than those from older systems of $\geq 3$ years with a sludge layer of about $10-25 \mathrm{~cm}$ thick. This observation suggested that hydrolysis and / or mineralization of POM progressively reduced the organic matter content of the deposits within the sludge layer. However, although COR, RAM and PRE samples were all taken from young plants (1 year and less), COR sample was less organic than those from RAM and PRE. have to be considered to explain this observation.

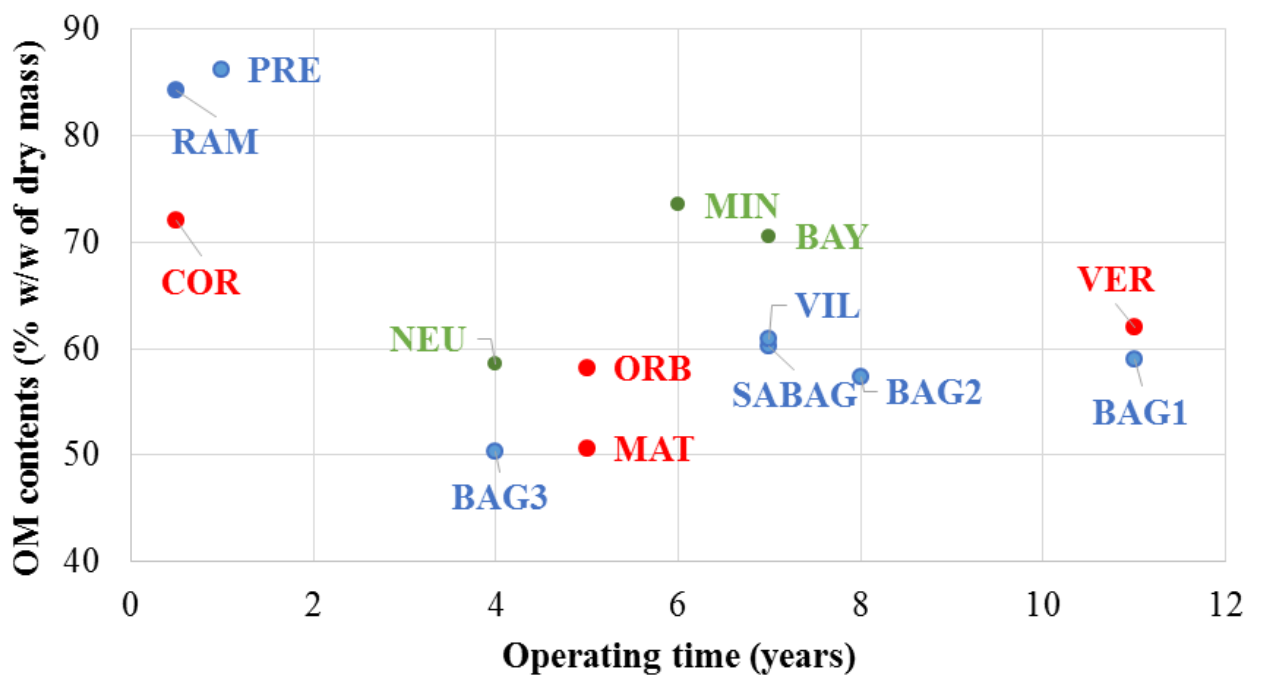

Operating time (years)

139 Fig. 1. Organic matter contents of the surface deposits versus operating time of their VFCW plants of origin. Blue dots: Classical French system with no additional treatment. Green dots: additional treatment on trickling filter only. Red dots: trickling filter and $\mathrm{FeCl}_{3}$ addition.

\subsubsection{Elemental compositions}


MAT, respectively), were two-fold higher than in the plants without any additional treatment

149 where $\mathrm{P}$ concentrations ranged between 0.5 and $1.2 \% \mathrm{w} / \mathrm{w}$ of dry matter. This result confirmed

150 the good efficiency of $\mathrm{FeCl}_{3}$ injection to precipitate phosphorus. The samples from plants with

151 a trickling filter also revealed slightly higher P contents $(1.2 \% ; 1.9 \%$ and $1.5 \%$ in NEU, BAY

152 and MIN samples respectively) than those with no additional treatment at all. This observation

153 could be attributed to the assimilation of phosphorus within the biofilm in the trickling filter,

154 which after detachment would be subsequently retained within the surface sludge layer and

155 induce a relative increase in P contents (Andersson, 2009). Total Nitrogen (TN) contents ranged

156 between 1.5 and $4.8 \%$ w/w of dry mass in all the samples. These results were close to those

157 reported in sludges from lagoons sewage treatment plants, but lower than those found in

158 suspended solids from activated sludge systems (Vincent, 2011). COR sample exhibited a TN

159 concentration of $4.1 \%$ w/w of dry mass, which was about double of the concentrations measured

160 in the samples of similar age RAM and PRE (1.5 and $2.1 \% \mathrm{w} / \mathrm{w}$ of dry mass, respectively). This

161 observation may be explained by the interactions (complexation, coagulation, precipitation) of

162 soluble N species with $\mathrm{FeCl} 3$ used in COR plant. Other authors (Boucher et al., 1999; Hamdani

163 et al., 2004; Poon \& $\mathrm{Chu}, 1999)$ reported the effect of $\mathrm{FeCl}_{3}$ on the removal of TN from dairy

164 effluents. This effect was observable here in young-age plants but not in older plants (Table 2),

165 showing that other ageing effects became predominant over the years of operation.

Table 2 showed that the contents in trace metals were in the same order of magnitude in

167 all the samples. The accumulation of trace metals and other micropollutants is a potential

168 environmental concern when considering land application or nutrients recovery from the

169 dredged sludge (Fang et al., 2016; Gautier et al., 2017; Kim et al., 2016; Peccia \& Westerhoff,

170 2015; Peysson et al., 2013). Total contents in $\mathrm{Cd}, \mathrm{Cr}, \mathrm{Ni}, \mathrm{Pb}, \mathrm{Cu}$ and $\mathrm{Zn}$ in the sludge deposits

171 analyzed here ranged in most cases between ca. 0.9 and 1.6, 35 and 74, 18 and 37, 32 and 69,

172196 and 425, 430 and 953 mg.kg DM ${ }^{-1}$ respectively. These concentrations were in the ranges 
173 classically reported in activated sludge, respectively 1-10 for $\mathrm{Cd}, 10-100$ for $\mathrm{Cr}, \mathrm{Ni}$ and $\mathrm{Pb}$ and 174 100-1000 mg.kg DM ${ }^{-1}$ for $\mathrm{Zn}$ and $\mathrm{Cu}$ (Lachassagne, 2015). A few samples revealed however 175 relatively high contents in some elements. Sludge deposits from SABAG plant exhibited a high 176 copper concentration (1162 mg.kg DM $\left.{ }^{-1}\right)$, samples from VER a high zinc concentration (1218.5 177 mg.kg $\mathrm{DM}^{-1}$ ) and samples from BAY a high lead contents (121.5 mg.kg $\left.\mathrm{DM}^{-1}\right)$. These 178 observations may be related to the specific nature of anthropic discharges (domestic, industrial 179 or both) to the sewage water in the water catchments of the respective constructed wetlands 180 (Chipasa, 2003; Ustun, 2009; Vriens et al., 2017). Table 2 showed the concentrations of trace metals analyzed in the 14 sludge deposit samples. As an informative reference, these concentrations may be compared to the upper limit concentrations of a series of trace metals 183 considered in French regulation for land application of sludge (decree $\mathrm{N}^{\circ}$ 97-1133 of 8/01/1998), 184 expressed in mg of element per kg of DM: Cd and $\mathrm{Hg} 10 \mathrm{DM}$; $\mathrm{Cr}$ and $\mathrm{Cu}$ 1000, Ni 200; $\mathrm{Pb} 800$; 185 $\mathrm{Zn} \mathrm{3000;} \mathrm{Cr}+\mathrm{Cu}+\mathrm{Ni}+\mathrm{Zn} 4000$. It was observed that the concentrations increased in time from around $780 \mathrm{mg} \cdot \mathrm{kg}^{-1}$ of DM in young plants RAM and PRE to $\geq 1200$ in the older "classical" VFCW plants, suggesting a progressive accumulation of trace metals in the sludge deposits 188 over the years of operation, which may be explained in part by their sorption onto POM and/or mineral fractions of the sludge deposits. The implementation of additional treatment did not induce observable differences of total metal concentration in the samples from mature plants.

191 The average concentrations were $1201 \pm 386$ mg.kg DM ${ }^{-1}$ in samples from classical VFCW (no 192 additional treatments), $1115 \pm 237 \mathrm{mg} \cdot \mathrm{kg} \mathrm{DM}^{-1}$ in samples from $\mathrm{AZOE}^{\circledR}$ treatment plants, and $1931529 \pm 450$ mg.kg DM${ }^{-1}$ in AZOE-NP ${ }^{\circledR}$ treatment plants. Regarding sludge deposits from the 194 young plants, the effect of $\mathrm{FeCl}_{3}$ addition (co-precipitation with and/or sorption onto flocculated 195 mineral and organic phases) may explain here again the observed difference between the samples from COR (ca 1711 mg.kg DM ${ }^{-1}$ ) and RAM and PRE (721 and 833 mg.kg DM ${ }^{-1}$ 197 respectively) as already discussed by El Samrani et al. (2008) and Fu \& Wang (2011). The 
situation in the sludge layer in the VFCW seems in many aspects comparable with the sludge

199 layer building up in SDRB systems. In sludges from reed bed systems, very similar contents 200 were indeed reported for TOC and TN (Masciandaro et al., 2017; Nielsen et al., 2014 ; Peruzzi

201 et al., 2013), and trace metals (Caicedo et al., 2015; Matamoros et al., 2012; Nielsen \& Bruun, 202 2015).

\subsection{Biodegradability of sludge deposits' organic matter}

Fig. 2 shows the results of cumulated $\mathrm{O}_{2}$ consumption measured over 14 days of 205 incubation at $30^{\circ} \mathrm{C}$ of the sludge deposits samples. It can be seen that the samples from the 206 mature plants exhibited respiration levels ranging between 200 and $500 \mathrm{mgO}_{2} \cdot \mathrm{TOC}^{-1}$ in 14 days 207 of incubation, which may be considered as low values according to the scale used for compost 208 (Wood et al., 2009) and with respect to the theoretical maximum of $2667 \mathrm{mg} \mathrm{O}$ per g of TOC.

209 These results therefore revealed the poor biodegradability and/or bioavailability of the organic 210 matter in these samples. The samples from the youngest three plants PRE, RAM and COR 211 exhibited drastically higher respiration levels $(1729,1387$ and $2577 \mathrm{mg} \mathrm{O}$ per $\mathrm{g}$ of TOC respectively), indicating that their organic matter was readily biodegradable and bioavailable in 213 the conditions of the assays. Vincent (2011) reported that fresh organic matter from raw 214 wastewater was responsible for the major part of $\mathrm{O}_{2}$ consumption in "classical French" VFCWs. 


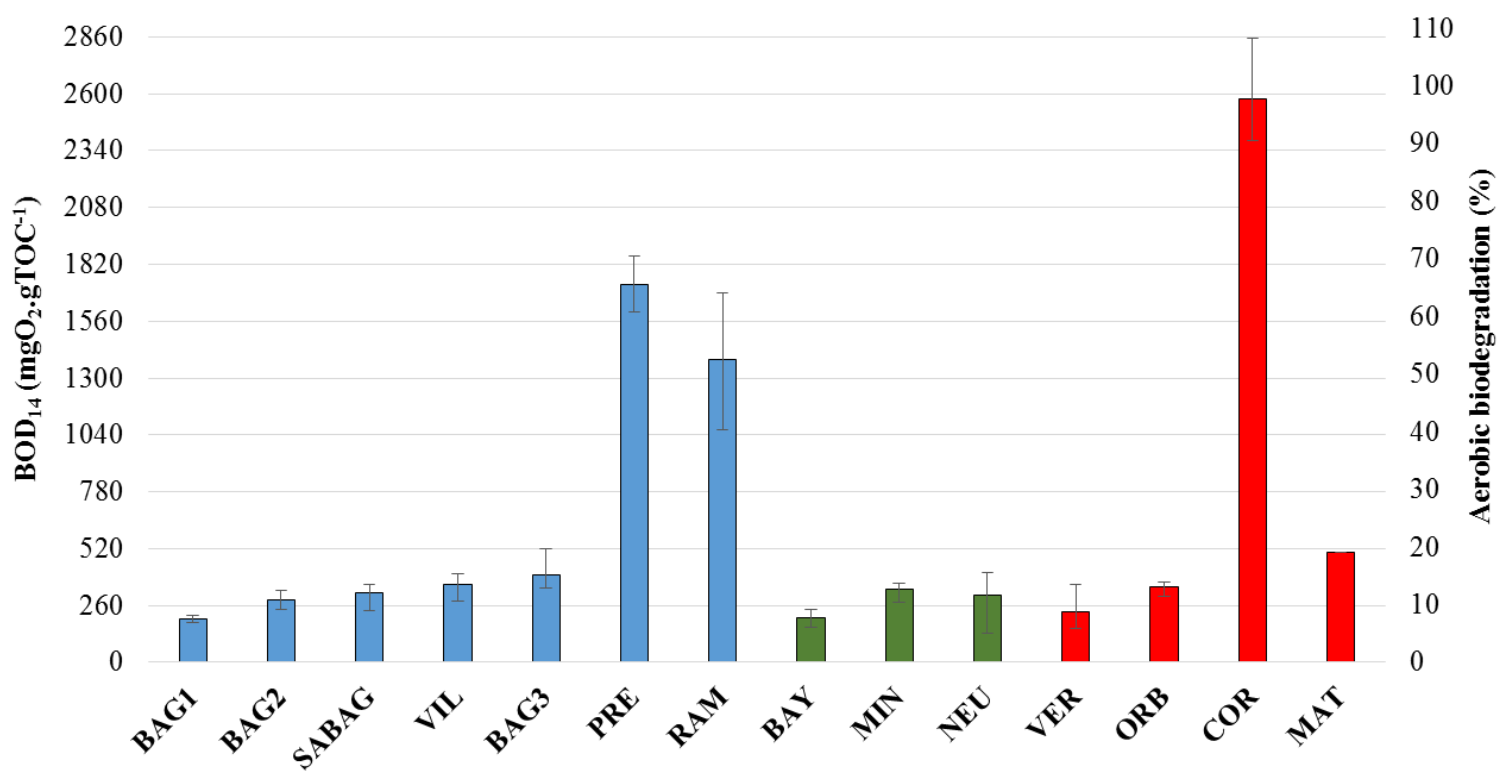

216 Fig. 2. Aerobic biodegradation measured over 14 days of incubation at $30^{\circ} \mathrm{C}$ on the surface sludge deposits sampled from French VFCW sewage treatment plants of different types. Classical system with no additional treatment (blue bars); additional treatment on trickling filter only (green); trickling filter and $\mathrm{FeCl}_{3}$ addition (red).

Results obtained from the analysis of sludge deposits from VFCW sewage treatment plants of increasing ages therefore showed that both the organic contents of the sludge deposits and the biodegradability of their organic matter decreased over time, suggesting the occurrence of both mineralization and humification processes. Similar phenomena were reported in other environmental media (Albrecht, 2007; Francou, 2003).

\subsection{Indicators of maturation of particulate organic matter}

\subsubsection{TOC/TN ratio}

$\mathrm{TOC} / \mathrm{TN}$ ratio is a parameter classically used to monitor the progress of biodegradation

228 in the processes of organic waste composting (Iglesias Jiménez \& Perez Garcia, 1989; Zahra El

229 Ouaqoudi et al., 2015). The ratio normally decreases over time since biodegradation releases

230 carbon (in the form of $\mathrm{CO}_{2}$ ) whereas nitrogen remains within the waste material during

231 composting operations. Compost is considered mature when the ratio falls below 15 (Zahra El

232 Ouaqoudi et al., 2015). Grimaud (1996) also reported that secondary sludge from conventional 
233 domestic wastewater treatment would exhibit a TOC/TN ratio between 6 and 12, whereas

234 primary sludge would be above 12.

Based on these studies, the ratio was tentatively used here as an indicator of the

evolution of organic matter in the sludge deposits. Table 2 showed that low values between 5.5 and 7.2 were measured in sludge deposits taken from VFCW plants of three years and more, whereas samples from the young plants RAM and PRE exhibited much higher values of 24.7 and 15.6 respectively. COR sample however, although also originating from a young plant, revealed a low TOC/TN value of 5.9. The ratio TOC/TN ratio was however considered nonrelevant as an indicator of POM evolution in VFCW. As a matter of fact, unlike composting where $\mathrm{N}$ is not exported from waste material, the conditions of evolution of surface sludge

243 deposits in VFCW allowed both the release of $\mathrm{N}$ in the form of soluble and leachable species 244 and/or the accumulation of $\mathrm{N}$ species from wastewater via complexation and/or adsorption. 245 Other authors (Brewer \& Sullivan, 2003; Huang et al., 2006) also reported that TOC/TN ratio 246 was not sufficient or not always relevant to discriminate the level of maturity of OM. Other 247 indicators widely used in published studies, such as the humification rate, were therefore 248 considered.

\subsubsection{Humification rate}

The contents in HULIS and FULIS fractions analyzed in the different samples, expressed as \% w/w of organic carbon, and the calculated humification rate are shown in Fig. 3. The humification rate of almost all the samples from mature plants were found to be relatively high and very similar, ranging from $27.9 \pm 0.5$ to $33.8 \pm 0.9 \% \mathrm{w} / \mathrm{w}$ of sludge TOC. This indicator

254 was therefore consistent with the results discussed above relative to the biostability of their 255 organic matter. Masciandaro et al. (2017) obtained very similar values (humification rate 256 between 23.7 and $30.4 \%$ ) in sludge treatment reed bed systems and concluded to the 257 effectiveness in stabilizing sludge organic matter. One sample however, also collected from a 
mature plant, MAT, exhibited on this indicator a much higher value than all other samples, as

259 high as ca. $46.4 \pm 2.8 \%$, suggesting that the organic matter in this sample was particularly 260 humified, although it did not exhibit the smallest biodegradability in Fig. 2. The particular 261 properties of this sample are discussed below.

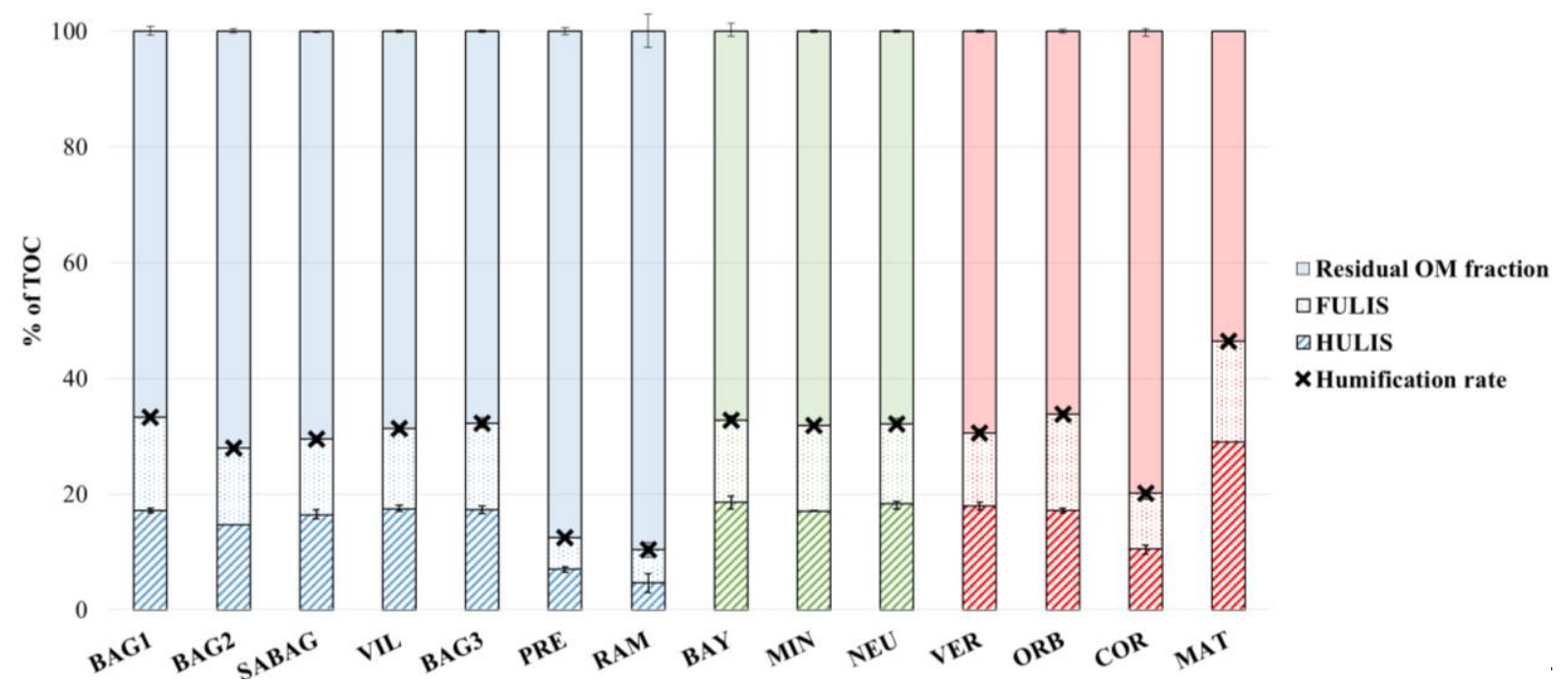

263 Fig. 3. Distribution of organic carbon in sludge deposits (SD) organic fractions, and humification rate 264 measured in the 14 VFCWs sludge deposits. Classical system with no additional treatment (blue); additional treatment on trickling filter only (green); trickling filter and $\mathrm{FeCl}_{3}$ addition (red).

Samples from the young plants RAM and PRE showed lower values of humification rates, $12.5 \pm 0.6$ and $10.3 \pm 2.9 \%$ respectively, which were relatively close to level reported for 268 activated sludge (16.5\% in Riffaldi (1982) and 10.9\% in Li et al. (2011)). COR sample however exhibited a humification rate of ca $20.1 \pm 1.6 \% \mathrm{w} / \mathrm{w}$ of TOC which was comprised between the levels measured in the other two young plants RAM and PRE and in mature plants. This observation was attributed to the transformation of the organic matter through the trickling filter and the detachment of biofilm fragments which may favor the formation of humic-like

273 substances as reported by other authors (Maeng et al., 2015; Zhao et al., 2013).

\subsection{Thermal analyses}

TGA and DSC profiles obtained from thermal analyses of the sludge deposits samples 276 are shown in Fig. 4 in the range of temperatures between $200^{\circ}$ and $600^{\circ} \mathrm{C}$ known to induce 
277 thermal degradation of organic compounds of natural origins (Torres-Climent et al., 2015). The

278 first part of the graphs, from $200^{\circ} \mathrm{C}$ to $400^{\circ} \mathrm{C}$, was considered to correspond to the degradation

279 of relatively labile organic compounds, such as hemicelluloses, cellulose and some aliphatic

280 compounds (Chen et al., 2015; Gomez et al., 2007; Som et al., 2009; Zahra El Ouaqoudi et al.,

281 2015). The second part between 400 and $600^{\circ} \mathrm{C}$ was considered associated to more complex

282 and stable organic compounds such as lignin and other high molecular weight poly-aromatic

283 structures such as humic and fulvic substances (Chen et al., 2015; Cuypers et al., 2002; Melis

284 \& Castaldi, 2004; Zahra El Ouaqoudi et al., 2015).
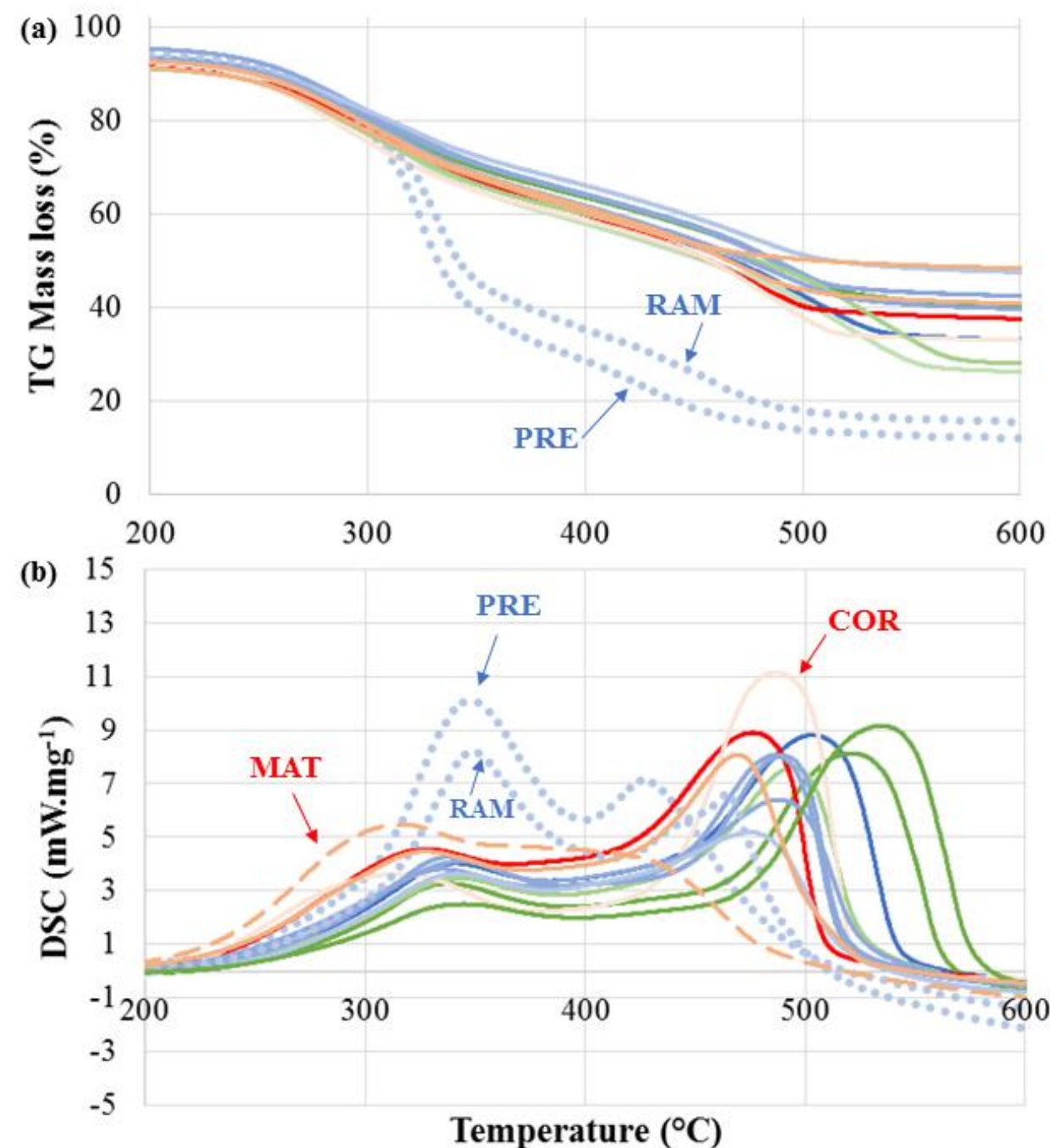

Temperature $\left({ }^{\circ} \mathrm{C}\right)$

286 Fig. 4. Mass loss (a) and differential scanning calorimetry (b) profiles recorded from surface sludge deposits from 14 French VFCW sewage treatment plants. Classical system with no additional treatment (blue); additional treatment on trickling filter only (green); trickling filter and $\mathrm{FeCl}_{3}$ addition (red). 
For all samples, except RAM and PRE, TGA profiles showed that around 1/4 to $1 / 3$ of

291 the initial dry mass ( 26.2 to $35.1 \%$ w/w of dry mass) was degraded between 200 and $400^{\circ} \mathrm{C}$.

292 The mass losses between 400 and $600^{\circ} \mathrm{C}$ were in the same order of magnitude as from 200 to $293400^{\circ} \mathrm{C}$, ranging between 19.8 and $32.4 \% \mathrm{w} / \mathrm{w}$ of dry mass. RAM and PRE samples, taken from 294 the youngest VFCW plants, exhibited different patterns, with about $2 / 3$ of initial dry mass 295 degraded between 200 and $400^{\circ} \mathrm{C}(66.4$ and $66.1 \% \mathrm{w} / \mathrm{w}$ of dry mass respectively), and only 296 around $16 \% \mathrm{w} / \mathrm{w}$ of initial dry mass degraded between 400 and $600^{\circ} \mathrm{C}$. Similar results were 297 reported for activated sludge by Magdziarz et al. (2013), with around 50\% degradation of initial 298 dry mass between 200 and $400^{\circ} \mathrm{C}$ and $20 \% \mathrm{w} / \mathrm{w}$ of dry mass above $400^{\circ} \mathrm{C}$. MAT sample 299 exhibited an atypical profile. Although between 200 and $400^{\circ} \mathrm{C}$ the mass loss was $32.0 \% \mathrm{w} / \mathrm{w}$ 300 of dry mass as in almost all samples, above $400^{\circ} \mathrm{C}$ the mass loss was the lowest of all samples $301(11.1 \%)$

The thermal degradation processes were logically exothermic since the analyses were made in the presence of air (DSC profiles in Fig. 4). The heat released per unit mass of organic 304 matter oxidized in the assays was related to the energy of inter-atomic bounds and the degree 305 of oxidation of carbon in the organic constituents. It can be observed that the ratio $\mathrm{E}_{1}$ between 306 200 and $400^{\circ} \mathrm{C}$ was much smaller than $\mathrm{E}_{2}$ between 400 and $600^{\circ} \mathrm{C}$ (Table 3). The thermal 307 degradation was therefore much less exothermic per unit mass of organic constituents below $400^{\circ} \mathrm{C}$ than above $400^{\circ} \mathrm{C}$. It was therefore concluded that the POM constituents degraded below $309400^{\circ} \mathrm{C}$ were composed of molecules such as carbohydrates with relatively weak inter-atomic 310 bounds such as $\mathrm{C}-\mathrm{O}, \mathrm{C}-\mathrm{C}$ and $\mathrm{C}-\mathrm{N}$ (activation energy of $350-412 \mathrm{~kJ} \cdot \mathrm{mol}^{-1}$ ) (Leinweber \& 311 Schulten, 1992), and a relatively high degree of oxidation of carbon indicative of the 312 oxygenation index of the molecules (Barré et al., 2016; Soucémarianadin et al., 2018). The 313 organic constituents degraded above $400^{\circ} \mathrm{C}$ were considered to contain more $\mathrm{C}=\mathrm{C}$ bounds of 314 higher energy (activation energy of 520-840 $\mathrm{kJ} \cdot \mathrm{mol}^{-1}$ ) such as in humic-like substances, lignin 

and lignocellulosic complexes (Magdziarz \& Wilk, 2013), with carbon at a lower degree of

316 oxidation, such as in (poly)-aromatic compounds (Leinweber \& Schulten, 1992).

Table $3 \mathrm{R}_{\mathrm{TGA}}, \mathrm{E}_{1}, \mathrm{E}_{2}$ and $\mathrm{R}_{\mathrm{DSC}}$ values for 14 VFCW sludge deposits.

\begin{tabular}{|c|c|c|c|c|}
\hline & \multirow{2}{*}{$\mathbf{R}_{\mathrm{TGA}}$} & $\mathbf{E}_{1}$ & $\mathbf{E}_{2}$ & \multirow{2}{*}{$\mathbf{R}_{\text {DSC }}$} \\
\hline & & \multicolumn{2}{|c|}{ J.mg-1 } & \\
\hline BAG1 & 0.95 & 8.6 & 20.7 & 2.4 \\
\hline BAG2 & 0.75 & 10.5 & 16.7 & 1.6 \\
\hline SABAG & 0.83 & 9.2 & 15.4 & 1.7 \\
\hline VIL & 0.77 & 8.9 & 19.1 & .2 \\
\hline BAG3 & 0.76 & 10.2 & 21.2 & 2.1 \\
\hline PRE & 0.24 & 8.9 & 24.1 & 2.9 \\
\hline RAM & 0.28 & 7.9 & 24.6 & 3.2 \\
\hline BAY & 0.92 & 6.6 & 16.3 & 2.5 \\
\hline MIN & 1.05 & 6.0 & 17.3 & 2.4 \\
\hline NEU & 0.85 & 8.0 & 17.7 & 2.2 \\
\hline VER & 0.76 & 11.7 & 22.0 & 1.9 \\
\hline ORB & 0.76 & 9.5 & 15.6 & 1.7 \\
\hline COR & 0.79 & 8.5 & 18.7 & 2.2 \\
\hline MAT & 0.35 & 13.6 & 18.7 & 1.4 \\
\hline
\end{tabular}

0.8 and 1.1, indicating the presence of relatively stable organic constituents. For comparison, compost is considered mature for an $\mathrm{R}_{\mathrm{TGA}}$ index above 0.8 (Som et al., 2009; Zahra El Ouaqoudi et al., 2015). $\mathrm{R}_{\mathrm{TGA}}$ indexes of PRE and RAM samples were 0.2 and 0.3 respectively, confirming

324 the previous discussions related to the predominance of labile organic compounds in these 325 samples and the lower humification rate. $\mathrm{R}_{\mathrm{DSC}}$ values were found between 1.6 and 3.2. Samples 326 from the young plants RAM and PRE showed a higher index than those from the mature plants, 327 confirming their lower stability (Achour, 2008). 
sample which did not feature a clear bimodal pattern but showed instead a peak around $320^{\circ} \mathrm{C}$

334 followed by a shoulder at $445^{\circ} \mathrm{C}$. The particularities of MAT sample are further discussed below.

\subsection{Multi-parameter cross-analysis of sludge deposits characteristics}

\subsubsection{Inter-comparison of the 14 sludge deposits}

A correlation analysis was conducted on the different parameters of OM maturity and stability used in this study. Results gathered in Table 4 showed that OM content was relatively correlated with aerobic biodegradation and $\mathrm{R}_{\mathrm{DSC}}$, and anti-correlated with the humification rate.

340 A high organic content was typical of young-age VFCW plants, where fresh organic matter was 341 readily biodegradable and poorly humified. $\mathrm{R}_{\mathrm{DSC}}$ index was anti-correlated with the 342 humification rate and $\mathrm{R}_{\mathrm{TGA}}$ was not significantly correlated to any other indexes.

Table 4 Correlation coefficients (and P-value) between the parameters of biological, chemical and thermal characterization. Correlation coefficients shown in bold were considered statistically significant, 345 with $\mathrm{P}<0.05$.

\begin{tabular}{|c|c|c|c|c|c|}
\cline { 2 - 6 } \multicolumn{1}{c|}{} & OM & Humification rate & $\begin{array}{c}\text { Aerobic } \\
\text { biodegradation }\end{array}$ & $\mathbf{R}_{\text {TGA }}$ & $\mathbf{R}_{\text {DSC }}$ \\
\hline OM & 1 & $\mathbf{- 0 . 8 3 4}\left(\mathbf{2 . 1 0}^{-4}\right)$ & $\mathbf{0 . 6 2 3}(\mathbf{0 . 0 2})$ & -0.363 & $\mathbf{0 . 8 2 8}\left(\mathbf{3 . 1 0}^{-4}\right)$ \\
\hline $\begin{array}{c}\text { Humification } \\
\text { rate }\end{array}$ & 1 & $\mathbf{- 0 . 7 0 2}(\mathbf{0 . 0 1})$ & 0.427 & $\mathbf{- 0 . 7 5 0}\left(\mathbf{2 . 1 0}^{-3}\right)$ \\
\hline $\begin{array}{c}\text { Aerobic } \\
\text { biodegradation }\end{array}$ & & 1 & -0.467 & 0.436 \\
\hline $\mathbf{R}_{\text {TGA }}$ & & & & 1 & -0.253 \\
\hline $\mathbf{R}_{\text {DSC }}$ & & & & & 1 \\
\hline
\end{tabular}

To allow a relevant and discriminant graphical representation of the different SD

samples with respect to their characteristics, the most discriminant parameter within each type

349 of analyses was selected (namely biological, thermochemical, and chemical analyses). Based on the results shown in the previous sections, biodegradability and humification were selected as the biological and chemical parameters. Based on the statistical correlation assessment, $\mathrm{R}_{\mathrm{TGA}}$ index was selected as the thermochemical parameter because it did not show significant 
353 correlations with the first two parameters according to Table 4, and was therefore considered

354 to provide independent additional information. The corresponding 3-D representation shown in

355 Fig. 5 clearly revealed distinct typologies of samples. A first group was identified with the

356 samples from the young-age VFCW plants RAM, PRE and COR. COR sample was positioned

357 slightly apart from RAM and PRE samples, underlining the influence of the additional

358 treatments on the characteristics of the sludge deposits within the young-age of the VFCW

359 plants. A second group was clearly formed with the samples from the mature plants. This group

360 was very homogeneous, revealing the very strong similarities in the characteristics of the sludge

361 deposits of the VFCW plants of three years of operation and more, regardless of the

362 implementation or not of additional treatments and other local conditions. Sludge samples from

363 mature VFCW plants exhibited a humification rate between 20 and 40\%, an OM biodegradation

364 rate between 0 and $35 \%$, and a $\mathrm{R}_{\mathrm{TGA}}$ between 0.75 and 1. Finally, MAT sample was excluded

365 from both previous groups in the graphical representation of Fig. 5. Its overall characteristics

366 were therefore distinct from either groups of young-age and mature VFCW plants. MAT plant

367 was actually an atypical VFCW plant as compared to the others. For example, a predominance

368 of baby's wipes was observed at the surface of the first filter when the sludge deposits were

369 sampled. These wipes are made of about $60 \%$ polyester and $40 \%$ cellulose for most of them

370 and affect the composition of the sludge deposits. Fig. 5 therefore allowed to clearly identify a

371 third group of samples whose characteristics revealed a particular situation. 


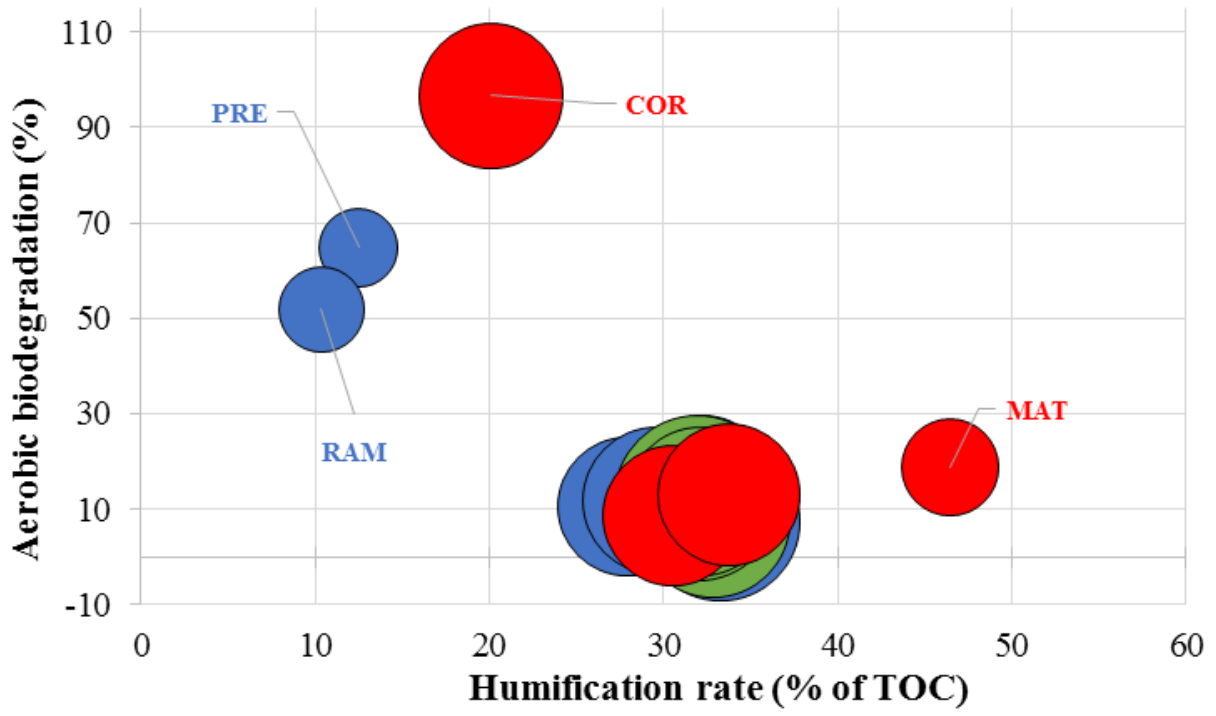

Fig. 5. Differentiation of sludge samples according to their indices related to the stability and maturity of the OM. Each sample is represented with a circle whose center is positioned according to the biodegradation rate and humification rate of the samples, and diameter is proportional to their $\mathrm{R}_{\mathrm{TGA}}$ indices. Classical system with no additional treatment (blue); additional treatment on trickling filter only (green); trickling filter and $\mathrm{FeCl}_{3}$ addition (red).

\subsubsection{Comparison to other samples at different levels of POM evolution}

Although some debates still remain on the subject, it is usually considered in the literature that ageing of natural particulate organic matter (POM) occurs via (i) the hydrolysis and mineralization of at least part of the most readily biodegradable constituents and (ii) the rearrangement of the remaining constituents into complex supra-structures usually called humus and usually considered as made of humic-like and fulvic-like substances. These phenomena are considered to increase (i) the proportion of HULIS+FULIS within the particulate organic matter and (ii) the proportion of HULIS vs. FULVIC within humus fraction. To assess the extents to which these processes occurred in the sludge deposits, Fig. 6 illustrates the plot of the ratio FULIS concentration/HULIS concentration of the samples as a function of the overall proportion of HULIS+FULIS within the total organic carbon of the samples. Data reported by Grasset et al. (2017) for different types of samples from natural systems were included in Fig. 6, along with other data calculated for activated sludges using the results of other studies (Li et al., 2011; Riffaldi, 1982). Fig. 6 illustrated the maturation pattern of natural organic matter from the early stages of evolution (fresh $\mathrm{OM}$ ) in the top left part to the mature 
state in the bottom right of the graph. The VFCW sludge deposits samples appeared as two

394 major groups in Fig. 6. The samples from young VFCW plants (RAM, PRE and to a lesser extent COR) constituted a first group situated at an earlier stage of maturation from the second between the young and mature groups, revealing the effects of the additional treatments

398 discussed previously.

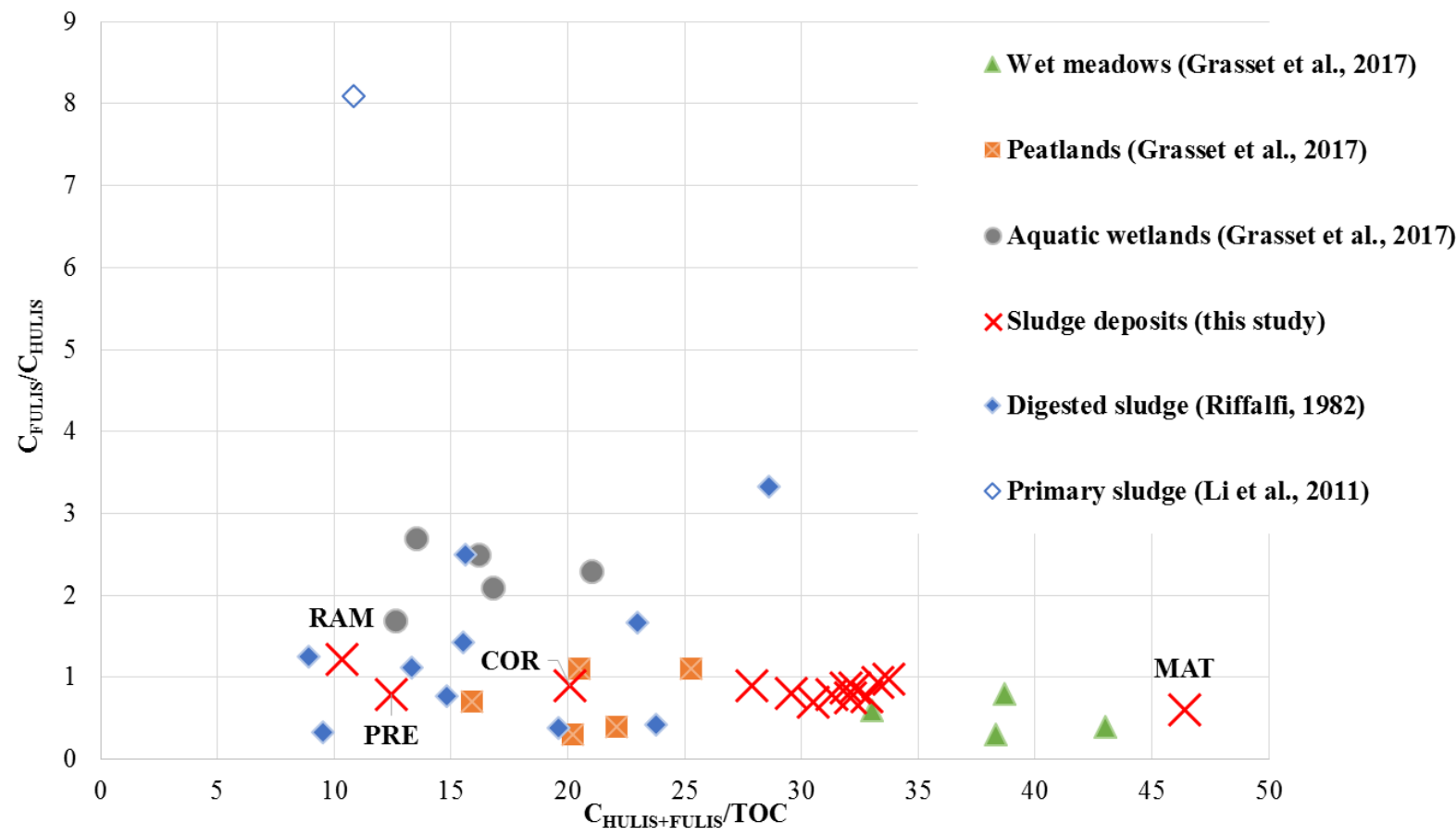

400 Fig. 6. $\mathrm{C}_{\mathrm{FULIS}} / \mathrm{C}_{\text {HULIS }}$ against $\mathrm{C}_{\text {HULIS }+ \text { FULIS }} / \mathrm{TOC}$ for natural wetlands (aquatic wetlands, peatlands and wet meadows), activated sludges and the 14 sludge deposits of this study.

Altogether, the spots showing the VFCW sludge deposits exhibited a specific state of evolution of the organic matter as compared to the other samples. Their position in the graph

404 revealed a specific typology of samples, despite the differences existing amongst them. Most 405 sludge deposits samples were positioned between the spot of digested sludge samples and 406 peatlands and the spot of wet meadows. On the contrary, RAM, PRE and COR samples were positioned close to the area of peatlands and digested sludge samples. 
410 sludge deposits sampled from 14 French VFCW sewage treatment plants. Results clearly

411 revealed the existences of two groups of samples. The dominant factor of distinction between

412 the two groups was the age of the VFCW plant of origin. The first group corresponded to sludge

413 deposits taken from VFCW plants which were still in their first year of operation at the time the

414 samples were collected. These samples exhibited a high content of organic matter of high

415 biodegradability, high thermal lability, and low humification. Although the number of samples

416 in this category (3) was low to permit a straightforward generalization, it was observed that the

417 implementation of additional treatments in one of the three VFCW plants of this group modified

418 the characteristics of its sludge deposits in terms of humification rate and thermal behavior.

419 This observation showed that the presence of additional treatments modified the characteristics

420 of the sludge deposits into a signature close to that of samples from mature systems. The second

421 group gathered samples from 10 distinct French VFCW plants in a remarkably homogenous

422 manner. The plants of origin were three years of age or more. Their sludge deposits were

423 characterized by a lower organic content, lower biodegradability and thermal lability, and

424 higher humification than those of the first group. This common set of properties was favorable

425 to a relative accumulation of trace metals, which were analyzed at higher concentrations in this

426 group of samples. However, the concentrations measured were found compatible with a land

427 application practice should the sludge have to be dredged out from the filters for maintenance.

428 One last sample, although originating from a mature VFCW plant, revealed quite different 429 properties as compared to the other ten samples of the group. This observation could not be 430 explained by the implementation of additional treatments. Rather, it revealed that the sample 431 was identified as "atypical", suggesting a particular situation in the VFCW plant of origin.

This study therefore showed that the organic matter captured within the surface sludge

433 layer in French VFCW sewage treatment plants was submitted to a relatively rapid evolution 
process over the very first year of operation of the plants. After one to three years of operation,

435 a certain equilibrium was established, resulting from the balance between the flow of fresh

POM continuously brought to the surface and the evolution of the rest of the deposits within

437 the depth of the layer. This equilibrium state was found to be remarkably similar in all the plants

438 of 3 years and more, regardless of the implementation of additional treatments, local conditions,

439 and time. Surface sludge deposits therefore appeared as integrative tracers of the evolution of

440 the system.

\section{Acknowledgments}

The authors would like to thank the technicians of DEEP laboratory Richard Poncet and Hervé Perier-Camby for their contributions, the SARM (Service d'Analyse des Roches et des Mineraux - CNRS - CRPG) and the ISA (Institut des Sciences Analytiques) for the elementary analyses. They are grateful to the reviewers for their contribution to the improvement of this manuscript, but also to SCIRPE and CIFRE (Conventions Industrielles de Formation pour la REcherche) for funding this research project.

\section{References}

Achour, F. 2008. PhD Thesis. Caractérisation de la Matière Organique dans les Ordures Ménagères - Recherche d'Indicateurs de Stabilité (Characterization of Organic Matter in Household Rubbish - Search for Stability Indicators). in: Industrial and Urban Environmental Sciences, The National Institute of Applied Sciences of Lyon. Lyon, France, pp. 173.

Albrecht, R. 2007. PhD Thesis. Co-Compostage de Boues de station d'épuration et de Déchets Verts (Co-Compostage of sludge from wastewater treatment plant and waste Green). in: Biosciences of Environment, University of Paul Cezanne, Aix-Marseille III. Marseille, France, pp. 189.

Alvarenga, P., Mourinha, C., Farto, M., Santos, T., Palma, P., Sengo, J., Morais, M.C., CunhaQueda, C. 2015. Sewage sludge, compost and other representative organic wastes as agricultural soil amendments: Benefits versus limiting factors. Waste management, 40, 44-52.

Andersson, S. 2009. PhD Thesis. Characterization of bacterial biofilms for wastewater treatment. in: School of Biotechnology, Royal Institute of Technology Stockholm, Sweden, pp. 63.

Badin, A.-L. 2009. PhD Thesis. Répartition et influence de la matière organique et des microorganismes sur l'agrégation et le relargage de polluants dans des sédiments (Distribution and influence of organic matter and microorganisms on the aggregation and release of pollutants in sediments). in: Industrial and Urban Environmental Sciences, National Institute of Applied Sciences of Lyon. Lyon, France, pp. 238.

Barré, P., Plante, A.F., Cécillon, L., Lutfalla, S., Baudin, F., Bernard, S., Christensen, B.T., Eglin, T., Fernandez, J.M., Houot, S., Kätterer, K., Le Guillou, C., Macdonald, A., van Oort, 
F., Chenu, C. 2016. The energetic and chemical signatures of persistent soil organic matter 471 Biogeochemistry, 130, 1-12.

472 Bellin, I. 2016. L'épuration végétalisée s'ouvre à de nouveaux marchés. L'eau, l'industrie, les 473 nuisances, 390, 67-76.

474 Bois, P., Laurent, J., Nuel, M., Wanko, A. 2015. Indicateurs de Colmatage de FPR à EV. Etude 475 comparative de 4 stations de traitement après 10 ans de fonctionnement. TSM Ingénierie 476 écologique, 9, 43-55.

477 Boucher, V., Revel, J.C., Guiresse, M., Kaemmerer, M., Bailly, J.R. 1999. Water, Air, and Soil 478 Pollution, 112(3/4), 229-239.

479 Brewer, L.J., Sullivan, D.M. 2003. Maturity and Stability Evaluation of Composted Yard 480 Trimmings. Compost Science \& Utilization, 11(2), 96-112.

481 Caicedo, P.V., Rahman, K.Z., Kuschk, P., Blumberg, M., Paschke, A., Janzen, W., Schüürmann, 482 G. 2015. Comparison of heavy metal content in two sludge drying reed beds of different age. 483 Ecological Engineering, 74, 48-55.

484 Chazarenc, F., Merlin, G. 2005. Influence of surface layer on hydrology and biology of gravel 485 bed vertical flow constructed wetlands. Water science and technology, 15( $\left.n^{\circ} 9\right), 91-97$.

486 Chen, J., Mu, L., Cai, J., Yin, H., Song, X., Li, A. 2015. Thermal characteristics and kinetics of 487 refining and chemicals wastewater, lignite and their blends during combustion. Energy 488 Conversion and Management, 100, 201-211.

489 Chipasa, K.B. 2003. Accumulation and fate of selected heavy metals in a biological wastewater 490 treatment system. Waste management, 23(2), 135-143.

491 Collard, M., Teychene, B., Lemee, L. 2017. Comparison of three different wastewater sludge 492 and their respective drying processes: Solar, thermal and reed beds - Impact on organic matter 493 characteristics. Journal of environmental management, 203(Pt 2), 760-767.

494 Cuypers, C., Grotenhuis, T., Nierop, K.G.J., Maneiro Franco, E., De Jager, A., Rulkens, W. 495 2002. Amorphous and condensed organic matter domains: the effect of persulfate oxidation on 496 the composition of soil/sediment organic matter. Chemosphere, 48, 919-931.

497 El Samrani, A.G., Lartiges, B.S., Villieras, F. 2008. Chemical coagulation of combined sewer 498 overflow: heavy metal removal and treatment optimization. Water research, 42(4-5), 951-60.

Fang, W., Wei, Y., Liu, J. 2016. Comparative characterization of sewage sludge compost and

501 Fernandez, J.M., Plaza, C., Polo, A., Plante, A.F. 2012. Use of thermal analysis techniques (TG502 DSC) for the characterization of diverse organic municipal waste streams to predict biological 503 stability prior to land application. Waste management, 32(1), 158-64.

504 Francou, C. 2003. PhD Thesis. Stabilisation de la matière organique au cours du compostage 505 de déchets urbains (Stabilization of organic matter in the urban waste composting). in: 506 Agricultural Sciences, National agricultural Institute Paris - Grignon. Paris, France, pp. 288.

507 Fu, F., Wang, Q. 2011. Removal of heavy metal ions from wastewaters: a review. Journal of 508 environmental management, 92(3), 407-18. 

purification performance of newly built constructed wetlands. Ecological Engineering, 83, 338 342.

512 Gautier, M., Kania, M., Merlot, L., Lupsea-Toader, M., Kim, B., Michel, P., Blanc, D., Gourdon, 513 R. 2017. Investigation of heavy metals leaching from VFCWs sludge deposit to evaluate 514 potential risks associated to land application. The 7th International Symposium for Wetland 515 Pollutant Dynamics and Control (WETPOL), Big Sky, Montana (USA), pp. 2.

516 Gomez, X., Cuetos, M.J., Garcia, A.I., Moran, A. 2007. An evaluation of stability by 517 thermogravimetric analysis of digestate obtained from different biowastes. Journal of hazardous 518 materials, 149(1), 97-105.

519 Grasset, C., Rodriguez, C., Delolme, C., Marmonier, P., Bornette, G. 2017. Can Soil Organic 520 Carbon Fractions Be Used as Functional Indicators of Wetlands? Wetlands, 37(6), 1195-1205.

521 Hamdani, A., Chennaoui, M., Assobhei, O., Mountadar, M. 2004. Caractérisation et traitement par coagulation-décantation d'un effluent de laiterie. Le Lait, 84(3), 317-328.

Hua, G., Kong, J., Ji, Y., Li, M. 2018. Influence of clogging and resting processes on flow patterns in vertical flow constructed wetlands. The Science of the total environment, 621, 11421150 .

Huang, G.F., Wu, Q.T., Wong, J.W.C., Nagar, B.B. 2006. Transformation of organic matter during co-composting of pig manure with sawdust. Bioresource technology, 97(15), 1834-1842.

Huot, H. 2013. PhD Thesis. Formation, fonctionnement et évolution d'un Technosol (Formation, functionning and evolution of a Technosol). in: Agronomic Sciences, National 530 School for Agronomy and Food Science - University of Lorraine. Vandoeuvre-lès-Nancy, 531 France, pp. 394.

532 Iglesias Jiménez, E., Perez Garcia, V. 1989. Evaluation of city refuse compost maturity: a 533 review Biological wastes, 27, 115-142.

Kania, M. (2018b). Caractérisation des dépôts de surface des filtres plantés de roseaux à écoulement vertical. Rôle et évolution de la matière organique particulaire. Doctoral thesis ; INSA de Lyon, France ; June 1st, 2018, 265 pages

Kania, M., Gautier, M., Ni, Z., Bonjour, E., Guégan, R., Michel P., James, P., Liu, J., Gourdon R. (2018a). Analytical indicators to characterize particulate organic matter evolutions in vertical flow constructed wetlands Science of the total environment, 622-623, 801-813.

Kania, M. Gautier, M., Michel P., Gourdon, R. (2018c) Study of aggregation in surface sludge deposits from 14 French vertical flow constructed wetlands using particle size distribution and dynamic vapor sorption analyses. Water Science \& Technology ,77(1), 79-90.

Kim, B., Gautier, M., Michel, P., Gourdon, R. 2013. Physical-chemical characterization of sludge and granular materials from a vertical flow constructed wetland for municipal

546 Kim, B., Gautier, M., Prost-Boucle, S., Molle, P., Michel, P., Gourdon, R. 2014. Performance 547 evaluation of partially saturated vertical-flow constructed wetland with trickling filter and 
chemical precipitation for domestic and winery wastewaters treatment. Ecological Engineering, 71, 41-47.

Kim, B., Gautier, M., Rivard, C., Sanglar, C., Michel, P., Gourdon, R. 2015. Effect of aging on phosphorus speciation in surface deposit of a vertical flow constructed wetland. Environmental science \& technology, 49(8), 4903-10.

Kim B., Gautier M., Simidoff A., Sanglar C., Chatain V., Michel P., Gourdon R. 2016 pH and Eh effects on phosphorus fate in constructed wetland's sludge surface deposit. Journal of Environmental Management. 183, 175-181;

Knowles, P., Dotro, G., Nivala, J., García, J. 2011. Clogging in subsurface-flow treatment wetlands: Occurrence and contributing factors. Ecological Engineering, 37(2), 99-112.

Lachassagne, D. 2015. PhD Thesis. Devenir de micropolluants présents dans les boues d'épuration, du traitement à l'épandage agricole : Application aux micropolluants métalliques $(\mathrm{Cd}, \mathrm{Cu})$ et organiques (médicaments) issus du traitement biologique conventionnel d'effluents urbains ou hospitaliers (Becoming of micropollutants in sewage sludge, from treatment to agricultural application: Application to metallic $(\mathrm{Cd}, \mathrm{Cu})$ and organic micropollutants (drugs) resulting from the conventional biological treatment of urban or hospital effluents). in: Environment Sciences, University of Limoges. Limoges, France, pp. 269.

Lee, C.G., Fletcher, T.D., Sun, G. 2009. Nitrogen removal in constructed wetland systems. Engineering in Life Sciences, 9, 11-22.

Leinweber, P., Schulten, H.-R. 1992. Differential thermal analysis, thermogravimetry and insource pyrolysis-mass spectrometry studies on the formation of soil organic matter. Thermochimica Acta 200, 151-167.

Li, X., Xing, M., Yang, J., Huang, Z. 2011. Compositional and functional features of humic acid-like fractions from vermicomposting of sewage sludge and cow dung. Journal of hazardous materials, 185(2-3), 740-8.

Liu, R., Zhao, Y., Doherty, L., Hu, Y., Hao, X. 2015a. A review of incorporation of constructed wetland with other treatment processes. Chemical Engineering Journal, 279, 220-230.

Liu, X., Bayard, R., Benbelkacem, H., Buffière, P., Gourdon, R. 2015b. Evaluation of the correlations between biodegradability of lignocellulosic feedstocks in anaerobic digestion process and their biochemical characteristics. Biomass and Bioenergy, 81, 534-543.

578 Maeng, M., Choi, E., Dockko, S. 2015. Reduction of organic matter in drinking water using a 579 hybrid system combined with a rock biofilter and membrane in developing countries. 580 International Biodeterioration \& Biodegradation, 102, 223-230.

581 Magdziarz, A., Wilk, M. 2013. Thermogravimetric study of biomass, sewage sludge and coal combustion. Energy Conversion and Management, 75, 425-430.

583 Masciandaro, G., Peruzzi, E., Nielsen, S. 2017. Sewage sludge and waterworks sludge 584 stabilization in sludge treatment reed bed systems. Water science and technology, 76(2), 355585363. 

fragrances, DEHP and heavy metals in a 20 years old sludge treatment reed bed system. Water research, 46(12), 3889-96.

589 Melis, P., Castaldi, P. 2004. Thermal analysis for the evaluation of the organic matter evolution 590 during municipal solid waste aerobic composting process. Thermochimica Acta, 413(1-2), 209591214.

592 Molle, P. 2014. French vertical flow constructed wetlands: a need of a better understanding of 593 the role of the deposit layer. Water Science and Technology, 69(1), 106-12.

594 Nielsen, S. 2005. Mineralization of hazardous organic compounds in a sludge reed bed and 595 sludge storage. Water Science \& Technology, 51(9), 109-117.

596 Nielsen, S. 2011. Sludge treatment reed bed facilities--organic load and operation problems. 597 Water science and technology, 63(5), 941-7.

598 Nielsen, S., Bruun, E.W. 2015. Sludge quality after 10-20 years of treatment in reed bed systems. 599 Environmental science and pollution research international, 22(17), 12885-91.

600 Nielsen, S., Peruzzi, E., Macci, C., Doni, S., Masciandaro, G. 2014. Stabilisation and 601 mineralisation of sludge in reed bed systems after 10-20 years of operation. Water science and 602 technology, 69(3), 539-45.

603 Nielsen, S., Willoughby, N. 2005. Sludge treatment and drying reed bed systems in Denmark. 604 Water and Environment Journal, 19, 296-305.

605 Nivala, J., Knowles, P., Dotro, G., Garcia, J., Wallace, S. 2012. Clogging in subsurface-flow 606 treatment wetlands: measurement, modeling and management. Water research, 46(6), 1625-40.

607 Peccia J. and Westerhoff P. 2015. We Should Expect More out of Our Sewage Sludge, 608 Environmental science \& technology, 49 (14), 8271-8276

609 Perron, V., Hébert, M. 2007. Caractérisation des boues d'épuration municipales. Vecteur 610 environnement, 48-52.

611 Peruzzi, E., Macci, C., Doni, S., Iannelli, R., Masciandaro, G. 2017. Stabilization process in 612 reed bed systems for sludge treatment. Ecological Engineering, 102, 381-389.

613 Peruzzi, E., Nielsen, S., Macci, C., Doni, S., Iannelli, R., Chiarugi, M., Masciandaro, G. 2013. 614 Organic matter stabilization in reed bed systems: Danish and Italian examples. Water science 615 and technology, 68(8), 1888-94.

616 Peysson, W., Vulliet, E. 2013. Determination of 136 pharmaceuticals and hormones in 617 sewage sludge using quick, easy, cheap, effective, rugged and safe extraction followed by 618 analysis with liquid chromatography-time-of-flight-mass spectrometry. Journal of 619 chromatography. A, 1290, 46-61.

Poon, C.S., Chu, C.W. 1999. The use of ferric chloride and anionic polymer in the chemically assisted primary sedimentation process. Chemosphere, 39(10), 1573-1582.

624 139-146. 

reduction affect the amount and apparent molecular weight distribution of dissolved organic matter in wetland soil: a laboratory study. Soil Research.

628 Semeraro, T., Giannuzzi, C., Beccarisi, L., Aretano, R., De Marco, A., Pasimeni, M.R., Zurlini, 629 G., Petrosillo, I. 2015. A constructed treatment wetland as an opportunity to enhance 630 biodiversity and ecosystem services. Ecological Engineering, 82, 517-526.

631 Serra-Wittling, C., Barriuso, E., Houot, S. 1996. Impact of composting type on composts organic matter characteristics. The Science of composting, Bertoldi edition, Bologne

Som, M.P., Lemee, L., Ambles, A. 2009. Stability and maturity of a green waste and biowaste compost assessed on the basis of a molecular study using spectroscopy, thermal analysis, thermodesorption and thermochemolysis. Bioresource technology, 100(19), 4404-16.

Soucémarianadin, L., Cécillon, L., Chenu, C., Baudin, F., Nicolas, Cyril Girardin, M., Barré, P. 2018. Is Rock-Eval 6 thermal analysis a good indicator of soil organic carbon lability? - A method-comparison study in forest soils. Soil Biology and Biochemistry 117, 108-116.

Stevenson, F.J. 1982. Humus chemistry: genesis, composition, reactions. John Wiley \& Sons, New York.

Torres-Climent, A., Gomis, P., Martin-Mata, J., Bustamante, M.A., Marhuenda-Egea, F.C., Perez-Murcia, M.D., Perez-Espinosa, A., Paredes, C., Moral, R. 2015. Chemical, Thermal and Spectroscopic Methods to Assess Biodegradation of Winery-Distillery Wastes during Composting. PloS one, 10(9), e0138925.

645 Ustun, G.E. 2009. Occurrence and removal of metals in urban wastewater treatment plants. Journal of hazardous materials, 172(2-3), 833-8.

Van Oostrom, A.J., Russell, J.M. 1994. Denitrification in constructed wastewater wetlands receiving high concentrations of nitrate. Water science and technology, 29(4), 7-14.

Vincent, J. 2011. PhD Thesis. Les lits de séchage de filtres plantés de roseaux pour le traitement de boues activées et les matières de vidange (Sludge drying reed beds for treatment of sludge activated and septage). in: Chemical Sciences and Food science, University of Montpellier II. Montpellier, France, pp. 236. of sludge deposit on sludge drying reed beds (SDRBs): influence of sludge characteristics and loading rates. Bioresource technology, 116, 161-9. Quantification of Element Fluxes in Wastewaters: A Nationwide Survey in Switzerland. Environmental science \& technology, 51(19), 10943-10953. - WRAP. 
664 Yang, M., Lu, M., Sheng, L., Wu, H. 2018. Study of the spatial and temporal distribution of 665 accumulated solids in an experimental vertical-flow constructed wetland system. The Science 666 of the total environment, 628-629, 509-516.

667 Zahra El Ouaqoudi, F., El Fels, L., Lemée, L., Amblès, A., Hafidi, M. 2015. Evaluation of 668 lignocelullose compost stability and maturity using spectroscopic (FTIR) and thermal 669 (TGA/TDA) analysis. Ecological Engineering, 75, 217-222.

670 Zhao, Q., Zhong, H., Wang, K., Wei, L., Liu, J., Liu, Y. 2013. Removal and transformation of 671 organic matters in domestic wastewater during lab-scale chemically enhanced primary 672 treatment and a trickling filter treatment. Journal of Environmental Sciences, 25(1), 59-68. 